\title{
Problematika Guru PPKn dalam Merancang dan Memanfaatkan Media Pembelajaran di SMAN 1 Koto Balingka Kabupaten Pasaman Barat
}

\author{
Hamami, Akmal \\ Prodi Pendidikan Pancasila dan Kewarganegaraan \\ FIS Universitas Negeri Padang \\ E-mail: amihamami45@gmail.com
}

\begin{abstract}
ABSTRAK
Penelitian ini dilatar belakangi oleh kurangnya pemahaman guru PPKn dalam merancang dan juga memanfaatkan media pembelajaran. Hal ini dikarenakan kurangnya penguasaan teknologi informasi yang diberikan guru kepada siswa dan tidak tersedianya sarana teknologi informasi dan komunikasi di Sekolah. Penelitian ini bertujuan untuk mengetahui tahap-tahap atau proses guru PPKn dalam merancang media pembelajaran di SMA N 1 Koto Balingka. Kemudian melihat bagaimana pemanfaatan media pembelajaran yang digunakan oleh guru PPKn, serta hambatan yang dialami oleh guru PPKn dalam merancang media pembelajaran di SMA N 1 Koto Balingka. Jenis penelitian yang digunakan dalam penelitian ini adalah deskriptif kualitatif, yaitu menggambarkan apa yang menjadi problematika guru PPKn dalam merancang media pembelajaran di SMAN 1 Koto Balingka, Kabupaten Pasaman Barat. Data dikumpulkan dengan teknik observasi, wawancara dan dokumentasi dengan menggunakan instrumen lembar observasi dan pedoman wawancara. Hasil penelitian ini menunjukkan bahwa Guru PPKn masih memiliki kesulitan dalam merancang media pembelajaran dan kurang memahami tahap-tahap atau proses dalam merancang media pembelajaran serta kurangnya pemahaman dalam pemanfaatan media pembelajaran di Sekolah.
\end{abstract}

Kata Kunci: guru PPKn, media pembelajaran, Koto Balingka

\section{ABSTRACT}

This research is motivated by the lack of understanding of Civics teachers in designing and also utilizing learning media. This is due to the lack of mastery of information technology provided by teachers to students and the unavailability of information and communication technology facilities in schools. This study aims to determine the stages or processes of PPKn teachers in designing learning media at SMA N 1 Koto Balingka. Then look at how the use of learning media used by PPKn teachers, as well as the obstacles experienced by PPKn teachers in designing learning media at SMA N 1 Koto Balingka. The type of research 
used in this research is descriptive qualitative, which describes what is the problem with PPKn teachers in designing learning media at SMAN 1 Koto Balingka, West Pasaman Regency. Data were collected by using observation, interview and documentation techniques using observation sheet instruments and interview guidelines. The results of this study indicate that Civics Teachers still have difficulties in designing learning media and do not understand the stages or processes in designing learning media and lack of understanding in the use of learning media in schools.

\section{Keywords: PPKn teacher, learning media, Koto Balingka}

(i) (?) This work is licensed under the Creative Commons Attribution-ShareAlike 4.0 International License. (c) 2021 by author.

\section{PENDAHULUAN}

Pendidikan merupakan kebutuhan mutlak bagi setiap orang melalui pengembangan pribadi dan sangat menentukan bagi kemajuan suatu bangsa dan negara. Pendidikan merupakan suatu kegiatan yang bertujuan untuk meningkatkan kualitas sumberdaya manusia dimana salah satu usaha untuk meningkatkan kualitas sumberdaya manusia tersebut melalui proses pembelajaran di sekolah. Dalam meningkatkan kualitas pendidikan pemerintah harus selalu berusaha meningkatkan kualitas serta proses pendidikan dari waktu ke waktu agar tujuan pendidikan dapat tercapai. Upaya peningkatan kualitas pendidikan juga dilakukan guru dengan berbagai macam strategi serta metode yang diajarkan kepada peserta didik untuk mencapai hasil pendidikan yang baik dan diiringi dengan media yang dapat meningkatkan kualitas pendidikan.

Menurut Arsyad (2011: 2-3) media adalah bagian yang tidak terpisahkan dari proses belajar mengajar demi tercapainya tujuan pendidikan. Media merupakan suatu alat yang digunakan guru untuk membantu proses belajar mengajar agar kegiatan pembelajaran tidak monoton yang dapat membuat peserta didik bosan dan mengakibatkan tidak tercapainya tujuan pendidikan. Media yang dirancang guru dalam proses belajar mengajar harus efektif dan mengandung hal yang positif dan dapat meningkatkan pengetahuan peserta didik agar media yang dirancang dapat digunakan secara efektif. Jika media yang dirancang guru tersebut disenangi peserta didik, hal tersebut dapat meningkatkan motivasi peserta didik dalam belajar serta dapat meningkatkan prestasi belajar peserta didik. Media pembelajaran yang dapat digunakan guru dalam proses belajar mengajar seperti media gambar, video, PPT, atau media pembelajaran lainnya yang menggunakan komputer.

Dalam penggunaan media yang baik pendidik harus menyediakan multimedia yang interaktif agar proses belajar mengajar dapat berjalan dengan lancar karena dengan adanya multimedia yang interaktif dapat meningkatkan minat belajar peserta didik. Minimnya 
pengetahuan guru merancang media pembelajaran yang akan digunakan guru dalam proses belajar mengajar dan kurangnya pengetahuan guru dalam memanfaatkan media pembelajaran merupakan suatu problematika yang harus diatasi untuk meningkatkan peserta didik yang intelektual. Problematika merupakan suatu kendala dimana hambatan dan kesulitan menjadi penghalang tercapainya suatu keinginan. Kendala seringkali terjadi dalam dunia pendidikan, seperti pada model pembelajaran, pendekatan, media pembelajaran dan penilaian pada siswa.

Berdasarkan pengamatan dan wawancara, peserta didik seringkali bosan dengan pembelajaran yang diberikan oleh guru tersebut, karena dalam penggunaan media pembelajaran guru kurang pandai merancang media yang menarik dan kurang memanfaatkan media yang ada. Kurangnya kemampuan guru dalam merancang media pembelajaran yang menarik merupakan suatu hambatan bagi guru untuk menciptakan proses pembelajaran yang efektif. Oleh sebab itu agar proses pembelajaran dapat menarik minat belajar peserta didik maka dibutuhkan media yang menarik sebagai penunjang berhasilnya suatu proses pembelajaran.

Sehubungan dengan permasalahan diatas maka peneliti ingin lebih mengetahui tentang problematika yang dialami guru dalam merancang dan memanfaatkan media pembelajaran agar suatu proses pembelajaran dapat berjalan efektif dan dapat meningkatkan minat belajar peserta didik. Penelitian ini bertujuan untuk mengetahui tahapan atau proses guru dalam merancang media pembelajaran, pemanfaatan media pembelajaran yang digunakan guru dan Problematika yang dialami guru tersebut dalam merancang media pembelajaran.

\section{METODE PENELITIAN}

Penelitian ini menggunakan metode deskriptif kualitatif yang digunakan untuk mendapatkan data primer maupun data sekunder. Penelitian ini dilakukan di SMAN 1 Koto Balingka, Kabupaten Pasaman Barat. Data didapatkan dari Guru dan peserta didik. Dalam penelitian ini teknik penentuan objek yang digunakan yaitu purposive sampling. Dalam mendapatkan data yang diinginkan maka peneliti menggunakan metode observasi, wawancara dan dokumentasi dengan menggunakan instrumen lembar observasi dan pedoman wawancara. Teknik analisis data yang digunakan berdasarkan pada analisis data menurut Milles dan A Hubberman (1984) dalam sugiyono (2005: 91) yang meliputi reduksi data, penyajian data dan pengambilan keputusan atau verifikasi. Dalam penelitian ini pengecekan keabsahan data penulis menggunakan teknik Triangulasi yaitu triangulasi sumber dan triangulasi metode. 


\section{HASIL DAN PEMBAHASAN \\ Tahap-tahap dalam merancang media pembelajaran oleh Guru PPKn}

Dalam merancang media pembelajaran seorang guru harus memperhatikan tahap-tahap yang ada dan proses yang akan dilakukan agar media pembelajaran yang dirancang oleh guru tersebut tidak memiliki kesalahan dalam menyampaikan materi yang akan disampaikan dengan begitu proses pembelajaran yang dilakukan dapat berjalan efektif. Tahap-tahap atau proses guru PPKn dalam merancang media pembelajaran yaitu: 1) Menyesuaikan presentasi Power Point yang akan digunakan dengan materi yang akan disampaikan; 2) Mencari bahan-bahan yang dapat digunakan pada saat merancang media Power Point; 3) Merangkum materi yang akan dimasukkan kedalam PowerPoint; 4) Membuat Power Point semenarik mungkin agar mudah dipahami oleh siswa; 5) Melakukan review terhadap media yang telah dibuat.

Dalam merancang sebuah media yang menarik tentunya harus belajar dengan memanfaatkan segala yang ada. Diantaranya dengan memanfaatkan sarana dan prasarana yang ada, cakap terhadap teknologi dan mengasah kemampuan atau keahlian yang dimiliki guru tersebut dalam merancang media pembelajaran. Dengan demikian maka akan akan tercipta media pembelajaran yang kreatif dan menarik. Dalam proses pembelajaran di kelas apabila guru memilih media pembelajaran yang tepat maka proses belajar mengajar yang dilakukan didalam kelas akan lebih efektif karena guru bisa menyesuaikan dengan keinginan peserta didik untuk menarik minat belajar peserta didik. Dengan begitu maka tujuan dapat tercapai dengan proses belajar mengajar yang dilakukan dengan media yang dirancang oleh guru tersebut se-kreatif mungkin. Serta memperhatikan tahapan dan proses yang baik dalam merancang media pembelajaran. Tahapan dalam pembuatan media merupakan hal yang sangat penting agar proses belajar mengajar yang diinginkan dapat berjalan dengan lancar sesuai dengan yang diharapkan oleh peserta didik dan juga guru tersebut.

\section{Problematika guru PPKn dalam merancang media pembelajaran}

Dalam merancang media pembelajaran yang kreatif seorang guru diharapkan memiliki kemampuan dan keahlian dalam merancang media tersebut agar dengan adanya media pembelajaran yang menarik sehingga mampu menarik minat belajar peserta didik atau meningkatkan motivasi belajar peserta didik. Pada saat merancang media pembelajaran yang kreatif, guru di SMAN 1 koto Balingka, Kabupaten Pasaman Barat memiliki kendala. Kendala tersebut diantara: 1) Merencanakan dan mengembangkan media yang sesuai dengan materi pembelajaran yang akan disampaikan; 2) kesulitan 
dalam merancang media pembelajaran PPKn yang berbasis teknologi; 3) keterbatasan kemampuan dan keterampilan dalam merancang media pembelajaran yang menarik; 4) keterbatasan sarana dan prasarana di sekolah. Problematika yang dialami guru tersebut merupakan pemicu penyebab kurang kreatifnya media pembelajaran yang dirancang oleh guru tersebut sehingga berdampak pada proses pembelajaran. Misalnya peserta didik yang kurang tertarik untuk belajar dan menimbulkan kebosanan dengan media yang dirancang guru tersebut kurang menarik. Hal tersebutlah yang harus diatasi guru dan juga sekolah agar proses pembelajaran dapat berjalan efektif dengan menggunakan media pebelajaran yang kreatif yang dirancang oleh guru.

Seorang guru harus merancang media berupa media visual, media audio dan media audio-visual dengan menggunakan berbagai macam multimedia yang ada. Problematika tersebut dapat diatasi dengan cara memanfaatkan segala sarana dan prasarana yang ada, selalu belajar dalam penggunaan teknologi dan benda-benda berteknologi lainnya dan juga mengasah kemampuan dan keahlian guru tersebut dalam merancang media pembelajaran yang kreatif.

\section{Pemanfaatan media pembelajaran oleh guru PPKn}

Pada saat merancang media pembelajaran, hal yang perlu diperhatikan adalah setelah kita merancang media pembelajaran tersebut apakah media tersebut bisa kita manfaatkan semaksimal mungkin atau tidak karena keberhasilan dalam proses belajar mengajar dikelas juga dilihat dari media pembelajaran yang digunakan oleh guru tersebut pada saat proses belajar mengajar di kelas. Media pembelajaran Power Point dapat dimanfaatkan oleh guru pada saat menyampaikan materi yang terlebih dahulu dilakukan dengan merancang media pembelajaran yang kreatif agar media PowerPoint tersebut dapat dimanfaatkan semaksimal mungkin.

Media pembelajaran yang kreatif akan meningkatkan semangat guru dalam menyampaikan materi pelajaran kepada peserta didik karena dengan pemanfaatan media pembelajaran semaksimal mungkin tentunya akan menciptakan proses belajar mengajar yang efektif dan juga berjalan dengan lancar. Saat guru memakai media pembelajaran tentunya kegiatan pembelajaran akan lebih menyenangkan dan pandangan peserta didik tentunya akan fokus kepada media yang dipakai guru saat memberikan pelajaran, dengan begitu proses pembelajaran tentunya akan lebih efektif.

\section{KESIMPULAN}

Tahap-tahap atau proses yang dilakukan guru PPKn pada saat merancang media pembelajaran seperti PowerPoint dengan menyesuaikan PowerPoint yang akan digunakan dengan materi yang akan disampaikan, mencari bahan-bahan yang dapat digunakan pada 
saat merancang media PowerPoint, Merangkum materi yang akan dimasukkan kedalam PowerPoint, Membuat PowerPoint semenarik mungkin agar mudah dipahami oleh siswa dan melakukan review terhadap media yang telah dibuat.

Dalam merancang media pembelajaran yang kreatif guru memiliki problematika yaitu dalam merencanakan dan mengembangkan media yang sesuai dengan materi pembelajaran yang akan disampaikan, kesulitan dalam merancang media pembelajaran PPKn yang berbasis teknologi, keterbatasan keterampilan dan kemampuan dalam merancang media yang menarik dan keterbatasan sarana dan juga prasarana. Dengan adanya media pembelajaran PowerPoint maka diharapkan dalam menyampaikan materi pelajaran menjadi lebih efektif, proses belajar mengajar dikelas menjadi lebih menarik, dapat terjadinya umpan balik antara siswa dan guru dan juga dengan adanya media pembelajaran diharapkan siswa dapat menyerap dan memahami materi yang diajarkan dikelas.

\section{DAFTAR PUSTAKA}

Sugiyono. 2015. Metode Penelitian Pendidikan Pendekatan Kuantitatif, Kualitatif dan R\&D. Bandung: Alfabeta

Said, Alwi.2017. Problematika Guru Dalam Pengembangan Media Pembelajaran. Jurnal Itqan, Vol 8. No 2.

Arikunto, Suharsimi. 2013. Prosedur Penelitian Suatu Pendekatan Praktik. Jakarta: Rineka Cipta

Marisa, dkk. 2012. Komputer dan Media Pembelajaran. Jakarta: Universitas Terbuka

Arsyad, Azhar. 2009. Media Pembelajaran. Jakarta: PT Raja Grafindo Persada

Dwi, Prastika, Santhy Hawanti, dkk. Permasalahan yang dihadapi Guru Dalam Pengelolaan dan Pemanfaatan Media Pembelajaran. Jurnal Inventa. Vol 3. No 